\title{
Sengketa Merek Prada dengan Merek The Rich Prada
}

\author{
Clarence Ritch Sutjipto (a)
}

(a) Fakultas Hukum Universitas Pelita Harapan, Clarenceritch10@gmail.com

\begin{abstract}
This article riviews Trademark cases about extension of the PRADA brand owned by PRADA S.A. and re-registration of THE RICH PRADA brand based on Trademark Law No. 15 of 2001 which is now changed to Law No. 20 of 2016 of Trademark. Therefore, there is a Directorate General of IPR that carries out its duties and functions in the process of trademark registration and others.

The case discussed in this article is regarding PRADA brand owned by PRADA S.A. who registered their brand in class 43 in 2007, but until 2017 PRADA S.A. absolutely not produce in class number 43. And an extension in 2018, and re-registration of THE RICH PRADA mark in indication of bad faith, the research method used in this article is normative juridical research that is research conducted with literature study, which refers to legal materials both primary and secondary legal materials related to this article.

The results of the article shows that if there are registered trademarks that register trademarks in the brand class but not used at all, it can still be extended as long as they do not exceed the grace period and in the registration of the mark, it should be in good faith.
\end{abstract}

Keywords: Trademark, trademark extension, trademark registration.

\section{Pendahuluan}

Hak Kekayaan Intelektual (HKI) merupakan padanan dari bahasa Inggris Intellectual Property Right. Kata "intelektual" tercermin bahwa obyek kekayaan intelektual tersebut adalah kecerdasan, daya pikir, atau produk pemikiran manusia. HKI adalah hak eksklusif yang diberikan kepada seseorang atau sekelompok orang atas karya ciptanya yang terdaftar. HKI secara sederhana mencakup dua bagian, Hak Cipta, dan Hak Kekayaan Industrial. HKI termasuk hak atas benda tak berwujud (seperti Paten, merek, hak cipta, dan sebagainya), berupa invensi dalam bidang ilmu pengetahuan, seni, sastra, teknologi, keterampilan dan sebaginya yang tidak mempunyai bentuk tertentu, yang memiliki nilai strategis bagi produsen maupun konsumen (Rifky Adrian 2016:2).

Merek menjadi faktor kunci dunia perdagangan dalam era perdagangan global, sejak industrialisasi berkembang. Peranan merek menjadi penting terutama untuk menghadapi

\section{Jurnal}

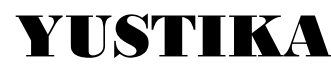

Media Hukum dan Keadilan Fakultas Hukum Universitas Surabaya Vol. 22 No. 2, Desember 2019 E-ISSN: 2655-7479 persaingan bisnis yang sehat. (Gloria Gita Putri Ginting, 2006:157) pada tahun 1883 berhasil disepakati Paris Convention for the Protection of Industrial Property (Konvensi Paris 1883) yang di dalamnya mengatur perlindungan merek terkenal, sedangkan di Indonesia merek sebagai salah satu HKI diatur dalam Undang-Undang Nomor 15 Tahun 2001 tentang Merek (selanjutnya disebut UU Merek). UU Merek telah melakukan penyempurnaan dan perubahan terhadap halhal yang berkaitan dengan merek guna disesuaikan dengan Konvensi Paris. Pada tahun 2016 
diundangkan Undang-Undang merek baru yaitu Undang-Undang No 20 tahun 2016 tentang Merek dan Indikasi Geografis (selanjutnya disebut UU MIG). Sebuah merek memiliki kedudukan yang begitu penting, sehingga kini banyak kasus mengenai perebutan dan pemalsuan merek dalam persaingan usaha. Merek walaupun sudah diatur sebegitu rupa dalam UU merek, namun tetap saja terjadi banyak duplikasi dan penyalahgunaan merek oleh para pelaku yang beritikad tidak baik. Fungsi dari pendaftaran merek pun disini adalah untuk menghindari adanya kecurangan dari pihak-pihak yang tidak memiliki merek namun menggunakannya yaitu dengan itikad tidak baik, termasuk perlindungan baik terhadap pengusaha merek terkenal juga terhadap pengusaha kecil (Thoyyibah, 2018:26). Secara singkat, itikad tidak baik atau bad faith adalah perilaku atau tindakan yang mengandung motif yang berkebalikan dari tindakan yang mendasarkan pada prinsip utmost good faith. Bad faith adalah tindakan yang dilakukan dengan didasari niat buruk. Tindakan seperti itu lazimnya disertai dengan niat melakukan kecurangan, baik secara nyata maupun yang masih dalam tahap rencana. Tujuannya, untuk mengelabui atau menyesatkan pihak lain, atau dalam batas tertentu bermaksud mengabaikan atau mengelak dari kewajiban yang harus dipenuhinya (Wijaya, 2018: 15)

Menurut Muhammad Djumhana merek haruslah dilindungi sebab: Merek dagang, kemasan, logo, dan slogan adalah aset perusahaan yang harus dilindungi, bukan saja karena semua itu dihasilkan lewat proses kreatif, melainkan karena semuanya merupakan ciri yang dipakai konsumen dalam mengenali suatu produk. Sistem yang digunakan HKI di Indonesia adalah "First to register" yaitu siapa yang mendaftarkan lebih dahulu, ialah yang memiliki hak eksklusif dari negara untuk jangka waktu tertentu menggunakan sendiri merek tersebut atau memberikan izin kepada pihak lain untuk menggunakannya.( Gatot Supramono, 2008:12) Walaupun di Indonesia menganut pendaftaran merek dengan sistem konstitutif, tentang merek terkenal yang belum terdaftar di Indonesia tetap akan mendapatkan perlindungan, karena Indonesia sudah meratifikasi Konvensi Paris dan perjanjian TRIPS (Tommy Hendra, 2017:42).

Produk-produk dengan merek yang terkenal akan lebih mudah untuk dipasarkan di masyarakat sehingga lebih mudah dalam hal pemasaran, dan memberikan keuntungan finansial lebih besar. Pengertian merek terkenal yaitum apabila merek telah beredar keluar dari batas-batas regional sampai batas-batas internasional dengan pembuktian adanya pendaftaran merek yang bersangkutan di berbagai Negeri (Putu Eka Krisna dan Dewa Gde Rudy (2018:5). terdapat sebuah kasus mengenai gugatan sengketa merek yang akan dibahas dalam jurnal ini. Kasus itu bermula saat PT.Gala Bumiperkasa, mengajukan hak merek "THE RICH PRADA" untuk kelas 43 yaitu penyedia makanan dan minuman, serta akomodasi sementara kepada Dirjen Kekayaan Intelektual (Dirjen KI) pada tanggal 26 November 2008. Dirjen KI setelah melakukan pemeriksaan lebih lanjut pada tanggal 29 Juli 2010, menolak pendaftaran merek "THE RICH PRADA". PT.Gala Bumi Perkasa yang merasa keberatan terhadap penolakan tersebut memberikan tanggapan atas penolakan Direktur Merek pada Dirjen KI tersebut pada tanggal 26 Agustus 2010. PT.Gala Bumi Perkasa juga mengajukan Surat Permohonan Hearing tertanggal 1 September 2010. Akibat permohonan Hearing tersebut, permintaan PT.Gala Bumi Perkasa dikabulkan dan memperoleh merek "THE RICH PRADA" untuk kelas 43. Merek milik PT.Gala Bumi Perkasa yaitu Merek “THE RICH PRADA" diumumkan tanggal 13 Oktober 2010 sampai dengan 13 Januari 2011 dalam berita Resmi Merek Seri A nomor 166/X/A/2010.

PRADA S.A. yang memiliki hak merek PRADA mengajukan keberatan terhadap merek "THE RICH PRADA" melalui surat keberatan oleh Kementerian Hukum dan Hak Asasi 
Jurnal Yustika

Vol. 22 No. 2, Des 2019

Halaman | 111 Sengketa Merek Prada dengan Merek The Rich Prada Clarence Ritch Sutjipto
Manusia Republik Indonesia Nomor H4.UM.02.02-26 tanggal 17 Januari 2011. PRADA S.A. yang memproduksi di bidang mode dengan merek "PRADA" telah mendaftarkan merek "PRADA" dalam kelas nomor 43 yaitu penyedia jasa untuk menyediakan makanan dan minuman; akomodasi sementara dengan nomor pendafaftaran IDM000216512 pada tanggal 28 April tahun 2007. Akan tetapi hingga saat ini PRADA S.A. sama sekali tidak memproduksi produk sebagaimana tertera dalam kelas nomor 43 sampai dengan kedaluwarsa 28 April 2017.

Atas keberatan PRADA S.A. maka Dirjen HKI mengabulkan sanggahan/keberatan itu dan terjadi penolakan merek "THE RICH PRADA" pada tanggal 22 Januari 2013 dengan alasan meniru merek orang lain yang sudah terkenal untuk jasa sejenis. PT. Gala Bumiperkasa keberatan atas keputusan itu, dan mengajukan banding pada Komisi Banding Merek. Pada 25 April 2013, Komisi Banding Merek menyatakan adanya persamaan antara "PRADA" dengan “THE RICH PRADA" sehingga "THE RICH PRADA" dicoret dari Daftar Merek. PT. Gala Bumiperkasa yang tidak terima dengan keputusan Dirjen HKI mengajukan gugatan terhadap putusan Komisi Banding ke Pengadilan Niaga Jakarta Pusat, dengan berdalih tidak ada persamaan antara merek miliknya dengan "PRADA". Pengadilan Niaga Jakarta Pusat dengan putusan Nomor 72/Pdt.Sus/Merek/2014/ PN.Niaga.Jkt.Pst., tanggal 10 Februari 2015 Pengadilan Niaga menolak gugatan Penggugat seluruhnya. PT. Gala Bumiperkasa kemudian mengajukan Kasasi. Majelis Hakim Agung dengan putusan Nomor 164 K/Pdt.Sus-HKI/2016 memutuskan menolak permohonan kasasi dari PT. Gala Bumiperkasa dan menghukum pemohon kasasi membayar biaya perkara. Pada saat ini merek PRADA milik PRADA S.A. yang telah kedaluwarsa pada 28 April 2017 melakukan perpanjangan merek pada 6 September 2018, serta merek "THE RICH PRADA" milik PT. Gala Bumiperkasa yang mendaftarkan ulang merek nya dengan nomor permohonan J102019057813 pada tanggal 1 Oktober 2019 dalam Dirjen KI. Didasarkan latar belakang di atas, maka rumusan masalah yang diangkat dalam jurnal ini adalah apakah pendaftaran merek THE RICH PRADA milik PT. Gala Bumiperkasa dapat diterima berdasarkan UU MIG? Dan apakah perpanjangan merek PRADA milik PRADA S.A. yang terlambat diajukan dapat diterima berdasarkan UU MIG?

\section{Metode Penelitian}

Tipe penelitian yang digunakan adalah tipe penelitian Yuridis Normatif, yang merupakan penelitian kepustakaan. Tipe penelitian Yuridis Normatif menganalisa bahan hukum yang dikaitkan dengan permasalahan yang ada yaitu mengenai akibat hukum yang dapat dilakukan terhadap merek PRADA dan THE RICH PRADA dalam perdagangan jasa berdasarkan Undang-Undang Nomor 20 Tahun 2016 tentang Merek dan Indikasi Geografis.

Pendekatan ini menggunakan pendekatan Perundang-undangan (Statute approach) adalah pendekatan yang dilakukan oleh peneliti melalui peraturan Perundang-undangan dan Pendekatan Konseptual (Conceptual approach) adalah pendekatan yang dilakukan oleh peneliti dengan membahas literatur dan asas-asas sebagai landasan pendukung.

Mengingat pengumpulan ini menggunakan Yuridis Normatif, maka metode yang digunakan adalah metode deduksi yaitu, analisa yang berawal dari sesuatu hal umum yang terdapat dalam peraturan perundang-undangan yang digunakan dalam penulisan ini yang kemudian berakhir pada sesuatu hal yang bersifat khusus yaitu diterapkan dalam permasalahan yang akan dibahas. Untuk memperoleh jawaban yang valid maka digunakan beberapa penafsiran yaitu: 
a. Penafsiran Otentik, adalah penafsiran yang pasti terhadap arti kata yang ditentukan dalam peraturan perundang-undangan.

Jurnal Yustika Vol. 22 No. 2, Des 2019

b. Penafsiran fungsional, adalah penafsiran yang dilakukan dengan memperhatikan fungsi (tujuan) yang harus dipenuhi oleh suatu UndangUndang. Fungsi (tujuan) dari suatu Undang-Undang (hukum) adalah memberikan keadilan hukum, kepastian hukum dan kemanfaatan hukum.

c. Penafsiran sistematis, yaitu membuat klasifikasi terhadap bahan-bahan hukum untuk memudahkan pekerjaan analisis dan konstruksi dengan cara menafsirkan dengan memperhatikan naskah-naskah hukum lain.

\section{Hasil Penelitian dan Pembahasan}

\subsection{Analisis Pendaftaran merek "THE RICH PRADA" menurut UU Merek dan Indikasi Geografis}

Berdasarkan kronologi kasus putusan MA nomor 164K/Pdt.Sus-HKI/2016 maka dapat diketahui bahwa Mahkamah Agung menyatakan merek "THE RICH PRADA" milik pihak PT. Gala Bumiperkasa ditolak atas dasar memiliki persamaan terhadap merek "PRADA" merek interasional milik Prada S.A. dengan alasan memiliki persamaan yang menonjol yang berpotensi menyesatkan konsumen, yang seolah-olah ada keterkaitan antara merek "THE RICH PRADA" dengan merek PRADA. Merek dibedakan menjadi merek dagang dan merek jasa, Dalam hal ini merek "THE RICH PRADA" yang mendaftar dalam kelas 43 dan merek "PRADA" juga terdaftar pada kelas 43 yang termasuk ke dalam merek jasa, dimana berdasarkan ketentuan Pasal 1 angka 3 UU Baru menentukan "Merek Jasa adalah merek yang digunakan pada jasa yang diperdagangkan oleh seorang atau beberapa orang secara bersamasama atau badan hukum untuk membedakan dengan jasa-jasa sejenis lainnya", maka dapat diketahui bahwa atas pendaftaran merek harus pula didukung dengan suatu produk jasa atau produk yang akan diperdagangkan. Demikian kenyataannya pemegang merek "PRADA" pada kelas 43 tidak memiliki bentuk produk nyata yaitu bidang usaha hotel dalam menjalankan jasanya, sedangkan pemegang merek "PRADA" telah mendapatkan hak atas merek tersebut sejak 28 April 2007, sehingga sangatlah tidak wajar apabila pemegang merek PRADA tersebut sampai saat ini tidak memiliki wujud produk (Hotel).

Putusan MA Nomor 1631 K/Sip/1978 yang telah menjadi yurisprudensi, dalam putusan itu disebutkan bahwa dalam hal terdapat rangkaian dua kata dalam satu merek, maka kata pertama lah yang memberikan kesan pokok. PT. Gala Bumiperkasa mendaftarkan mereknya yaitu "THE RICH PRADA" penekanan unsur pokok dalam merek tersebut pada kata pertama yaitu kata "THE RICH" sehingga unsur merek yang menonjol adalah unsur merek "THE $\mathrm{RICH}^{\prime \prime}$, Dalam sebuah bisnis barang atau jasa, merek merupakan daya pembeda. Karena itu, tidak dapat disebut sebagai merek apabila tidak memiliki pembeda dengan merek lainnya. Merek dikatakan berbeda apabila tidak memiliki persamaan dengan merek lainnya.(Benny Muliawan 2013:6)

Wajib dibuktikan terlebih lebih dahulu mengenai kebingungan yang nyata (actual confusion) atau menyesatkan (decieve) masyarakat konsumen, berkaitan dengan Merek "THE RICH PRADA" dengan Merek "PRADA". Merek "THE RICH PRADA" milik PT. Gala Bumiperkasa mengandung persamaan pada pokoknya dengan merek barang sejenis yang lebih dulu dikenal/terdaftar merek "PRADA" milik PRADA S.A. kemudian mengungkapkan bahwa
Halaman | 112

Sengketa Merek

Prada dengan

Merek The Rich

Prada

Clarence Ritch Sutjipto 
Jurnal Yustika

Vol. 22 No. 2, Des 2019

Halaman I 113 Sengketa Merek Prada dengan Merek The Rich Prada Clarence Ritch Sutjipto persamaan yang menonjol adalah kata "PRADA" yang berpotensi menyesatkan konsumen, yang seolah-olah ada keterkaitan dengan merek "PRADA" milik PRADA S.A. untuk barang yang sejenis.

Pasal 21 ayat (3) UU MIG mengatur mengenai permohonan yang ditolak terkait pemohon yang beritikad tidak baik "Permohonan ditolak jika diajukan oleh Pemohon yang beritikad tidak baik". Beritikad tidak baik disini dijelaskan dalam bagian penjelasan pasal 21 ayat (3) UU MIG yaitu :

Maksud dari "Pemohon yang beriktikad tidak baik" adalah Pemohon yang patut diduga dalam mendaftarkan Mereknya memiliki niat untuk meniru, menjiplak, atau mengikuti Merek pihak lain demi kepentingan usahanya menimbulkan kondisi persaingan usaha tidak sehat, mengecoh, atau menyesatkan konsumen.

Berdasarkan uraian di atas, maka analisa penulis pendaftaran merek "THE RICH PRADA" dengan nomor J102019057813 telah melanggar pasal 21 ayat (3) tentang permohonan yang beritikad tidak baik, dan pasal 21 ayat (2) huruf a tentang merek dari sebuah nama badan hukum, sehingga permohonan pendaftaran merek "THE RICH PRADA" dapat berakibat

ditolak oleh Dirjen KI.

Pada dasarnya, untuk menentukan apakah merek tersebut beritikad tidak baik atau tidak, apakah suatu merek memiliki persamaan pada keseluruhannya atau pada pokoknya perlu memperhatikan penjelasan pasal 21 UU MIG. Akan tetapi, UU MIG tidak menjabarkan pengertian persamaan pada keseluruhannya. Pengertian persamaan pada pokoknya adalah kemiripan yang disebabkan oleh adanya unsur-unsur yang menonjol antara merek yang satu dan merek yang lain,yang dapat menimbulkan kesan adanya persamaan baik mengenai bentuk, cara penempatan, cara penulisan atau kombinasi antara unsur-unsur atau pun persamaan bunyi ucapan yang terdapat dalam merek tersebut.

M. Yahya Harahap yang menyatakan bahwa: "Persamaan pada keseluruhan adalah persamaan seluruh elemen. Persamaan yang demikian sesuai dengan doktrin entires similar atau sama keseluruhan elemen".(Suyud Margono,2011:180) Dengan kata lain, merek yang dimintakan pendaftarannya merupakan tiruan atau reproduksi merek orang lain. Merek dapat disebut tiruan atau reproduksi merek orang lain,

Bahwa apabila merek "THE RICH PRADA" tersebut pada akhirnya berhasil didaftarkan kembali jika didaftarkan ulang tanpa adanya penolakan,keberatan dan atau sanggahan maka merujuk pada pasal 77 ayat (2) UU MIG menyatakan bahwa:

Gugatan pembatalan dapat diajukan tanpa batas waktu jika terdapat unsur iktikad tidak baik dan atau Merek yang bersangkutan bertentangan dengan ideologi negara, peraturan perundang-undangan, moralitas, agama, kesusilaan, dan ketertiban umum. Pasal 77 ayat (2) di dalam UU MIG yang memasukan gugatan pembatalan dapat diajukan tanpa batas waktu jika terdapat unsur iktikad tidak baik ini telah menjadikan UU MIG lebih ketat terhadap adanya merek-merek yang didaftar karena adanya itikad tidak baik dengan memberikan kesempatan tanpa batasan waktu kepada pihak penggugat untuk melakukan gugatan pembatalan merek.

\subsection{Analisis perpanjangan merek PRADA milik PRADA S.A. yang terlambat diajukan berdasarkan UU Merek dan Indikasi Geografis.}

Berdasarkan kronologi kasus diatas, Merek PRADA milik PRADA S.A. merupakan merek terkenal yang berasal dari Luxembourg, Italy. Merek PRADA terdaftar di Indonesia dengan nomor daftar IDM000216512 dalam kelas klasifikasi merek 43 yaitu penyedia makanan dan 
minuman, serta akomodasi sementara sejak tanggal 28 April tahun 2007 dengan perlindungan selama 10 tahun sesuai pasal 35 ayat (1) UU MIG maka kedaluwarsa pada tanggal 28 April 2017 dan belum pernah dipakai dalam perdagangan. Kemudian PRADA S.A. mengajukan perpanjangan merek pada tanggal 6 September 2018.

Perlindungan merek bertujuan untuk memastikan bahwa pemegang/pemilik merek harus menggunakan mereknya. Pemilik merek yang telah kehabisan masa perlindungan nya dan jika ingin memperpanjang perlindungan atas hak merek tersebut dapat melakukan perpanjangan sebagaimana diatur dalam pasal 35 ayat (2) UU MIG jangka waktu pelindungan sebagaimana dimaksud pada ayat (1) dapat diperpanjang untuk jangka waktu yang sama. UU MIG pasal 36 mengatur:

Permohonan perpanjangan disetujui jika Pemohon melampirkan surat pernyataan tentang:

a. Merek yang bersangkutan masih digunakan pada barang atau jasa sebagaimana dicantumkan dalam sertifikat Merek tersebut; dan

b. barang atau jasa sebagaimana dimaksud dalam huruf a masih diproduksi dan/atau diperdagangkan.

Dalam pasal 36 tersebut mengatur bahwa untuk perpanjangan sebuah merek wajib memberikan pernyataan bahwa merek tersebut masih digunakan pada perdagangan di masyrakat umum dan hal barang maupun jasa.

Dalam hal melakukan perpanjangan merek diatur berdasarkan pasal 35, 36, dan 38 UU MIG, bahwa untuk melakukan sebuah perpanjangan merek dibutuhkan pernyataan dari pemilik merek bahwa barang atau jasa tersebut masih digunakan dalam perdagangan, apabila merek tersebut berupa logo maka tidak memerlukan sesuai ketentuan pasal 36 UU MIG.

Merek PRADA dengan nomor daftar IDM000216512 yang terdaftar pada hari sabtu 28 April tahun 2007 maka sesuai pasal 35 UU MIG akan kedaluwarsa pada tahun 28 April 2017 dan apabila ingin diperpanjang memerlukan pengajuan perpanjangan Merek kepada Dirjen KI, dalam perpanjangan merek memilik masa grace periode yaitu masa tenggang waktu dengan tenggang waktu maksimal 6 bulan, maka apabila merek PRADA yang memiliki waktu kedaluwarsa pada 28 April 2017, maka terhitung 6 bulan setelah bulan April 2017 yaitu bulan Oktober 2017 maksimal waktu pengajuan perpanjangan merek oleh pihak PRADA. Berdasarkan kasus yang ada pada saat ini, PRADA milik PRADA S.A. melakukan perpanjangan tertulis dengan nomor pendaftaran JID2018043599 tanggal penerimaan 6 September 2018 yang diumumkan pada tanggal 24 September 2018. Berdasarkan kasus yang ada diatas, maka analisis merek PRADA berdasarkan pasal 35 UU MIG tentang tenggang waktu, maka merek PRADA telah melewati batas waktu yang ditentukan oleh UU MIG yaitu 6 bulan maksimal setelah habisnya perlindungan merek sesuai dengan nomor daftar IDM000216512 yaitu pada tanggal 28 April tahun 2017. Pasal 36 UU MIG yang mengatur mengenai pernyataan bahwa merek tersebut masih diperdagangkan sesuai dalam kelas tersebut tidak dapat ditemukan bahwa merek PRADA memilliki produk dalam kelas tersebut yaitu kelas 43, sehingga tidak memenuhi isi ketentuan pada pasal tersebut.

Pasal 38 UU MIG, mengesampingkan ketentuan pasal 35 dan 36 yaitu apabila perpanjangan Merek terdaftar berupa logo, dimana nyatanya merek milik PRADA S.A. merupakan nama badan hukum sendiri yaitu PRADA. Menurut analisis penulis perpanjangan perlindungan merek dari PRADA milik PRADA S.A. telah menyalahi beberapa aturan dalam Pasal-pasal yang telah dikemukakan diatas, yaitu telah melewati tenggang waktu sebagaimana diatur dalam pasal 35 UU MIG, kemudian telah menyalahi aturan pasal 36 UU MIG mengenai 
Jurnal Yustika

Vol. 22 No. 2, Des 2019

Halaman | 115

Sengketa Merek

Prada dengan Merek The Rich

Prada

Clarence Ritch Sutjipto syarat bahwa pernyataan merek masih digunakan dalam perdagangan barang atau jasa, tetapi merek PRADA dapat menggunakan pasal 38 UU MIG, yaitu sebuah nama badan hukum sendiri sehingga dapat didaftar kembali setelah memiliki kekuatan hukum tetap.

\section{Kesimpulan}

Perpanjangan perlindungan merek PRADA dapat berakibat tidak diterima oleh Dirjen KI, apabila merek PRADA milik PRADA S.A. telah terlambat mengajukan perpanjangan perlindungan merek berdasarkan UU MIG (pasal 35 ayat (3) UU MIG). Merek PRADA telah mengesampingkan mengenai hendaknya menyertakan surat pernyataan bahwa merek tersebut masih digunakan dalam perdagangan barang dan atau jasa (pasal 36 UU MIG), tetapi PRADA masih dapat menggunakan logo dengan dasar pasal 38 UU MIG dengan perpanjangan atas dasar badan hukum.

Pendaftaran ulang merek THE RICH PRADA milik PT. Gala Bumiperkasa dapat berakibat ditolak oleh Dirjen KI. Karena telah melanggar pasal 21 ayat (3) UU MIG tentang permohonan yang beritikad tidak baik karena telah meniru atau mendompleng merek PRADA milik PRADA S.A., dan pasal 21 ayat (2) huruf a tentang merek dari sebuah nama badan hukum, sehingga permohonan pendaftaran merek "THE RICH PRADA".

\section{Daftar Referensi}

Buku

Benny Muliawan. (2013). 8 Jalur Mendapatkan Merek Terdaftar, Jakarta: Neo Mediatama.

Gloria Gita Putri Ginting. (2006) .Perlindungan Hukum Merek Terkenal Tidak Terdaftar di Indonesia, Jakarta: Jurnal Gloria Juris.

Muhammad Djumhana. (2006). Perkembangan Doktrin dan Teori Perlindungan Hak Kekayaan Intelektual, Bandung: PT Citra Aditya Bakti.

Suyud Margono. (2011). Hak Milik Industri: Pengaturan dan Praktik di Indonesia. Bogor: Ghalia Indonesia.

Supramono Gatot. (2008). Menyelesaikan Sengketa Merek Menurut Hukum Indonesia. Jakarta: Rineka Cipta.

Tommy Hendra Purwaka .(2017). Pelindungan Merek. Jakarta : Yayasan Pustaka Obor Indonesia. 


\section{Jurnal}

Putu Eka Krisna. Dewa Gede Rudy. (2018). Perlindungan Hukum Terhadap Hak Merek Terkenal di Indonesia. Kertha Semaya : Journal Ilmu Hukum. 1(6). 1-12.

Rifky Ardian Nugroho. Budi Santoso. Siti Mahmudah. (2016). Perlindungan Hukum Pemegang Hak Merek Dagang Terkenal Asing (Well Known Mark) dari Tindakan Passing Off (Studi Sengketa GS Atas Nama GS Yuasa Corporation). Diponegoro Law Journal. 5(3). 1-18.

Thoyyibah Bafadhal. (2018). Perlindungan Hukum terhadap Merek Terkenal di Indonesia: Kasus IKEA. Undang : Jurnal Hukum. 1(1). 21-41. htpps://doi.org/10.22437/ujh.1.1.21-41

Wijaya Wilson. (2018). Analisis Kekuatan Unsur Itikad Baik Pada Pelaksanaan Pendaftaran Merek Di Indonesia (Studi Kasus Putusan Mahkamah Agung Nomor 364k/Pdt.Sus-Hki/2014) Berdasarkan Undang-Undang Nomor 20 Tahun 2016. Jurnal Hukum Adigama. 1(1).
Jurnal Yustika Vol. 22 No. 2, Des 2019

Halaman | 116 Sengketa Merek Prada dengan Merek The Rich Prada Clarence Ritch Sutjipto 